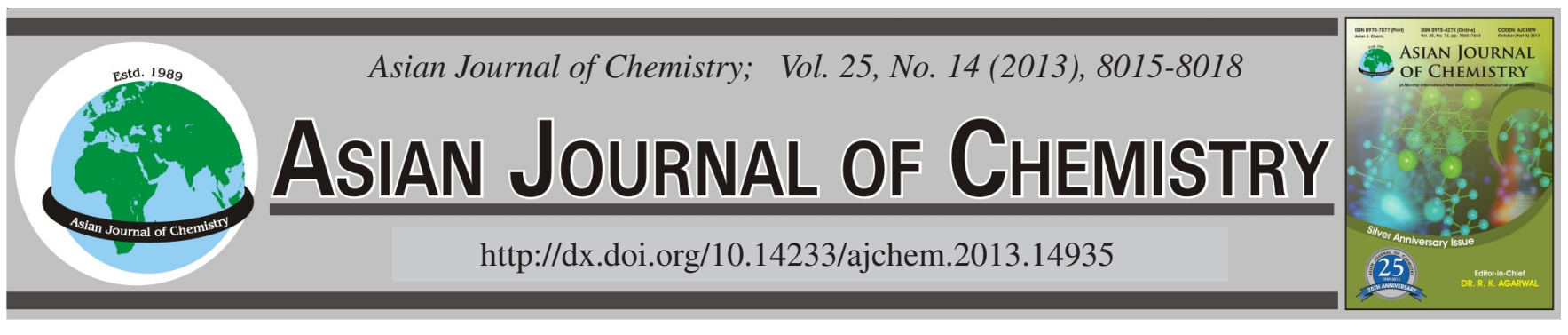

\title{
Risk Assessment of Chlorinated Effluents from Pulp and Paper Industry and Their treatment by Advanced Oxidation Process
}

\author{
Ramiah Gunasekaran* and Sellappa Kanmani
}

Environmental Engineering, Centre for Environmental Studies, Anna University, Chennai-600 025, India

*Corresponding author: Tel: +91 4324 230522; E-mail: gunshaswapre@gmail.com

This study presents performance of wet air oxidation in degradation of pulp and paper black liquor, optimization of operating parameters and process kinetics. The $\mathrm{pH}$, contact time and catalysts dosage were found optimized at 11, 180 min and 4 $\mathrm{mg} / \mathrm{L}$, respectively. The percentage of COD degradation was in the range of 27 to 47 without catalyst, 35 to 58 with catalyst $\mathrm{CuSO}_{4}$ and 46 to 65 with catalyst $\mathrm{TiO}_{2}$, respectively for the $\mathrm{pH}$ optimization, in the range of 18 to 61 without catalyst, 20 to 66 with catalyst $\mathrm{CuSO}_{4}$ and 30 to 71 with catalyst $\mathrm{TiO}_{2}$, respectively for the contact time optimization and in the range of 63 to 69 with catalyst $\mathrm{CuSO}_{4}$ and 68 to 74 with catalyst $\mathrm{TiO}_{2}$, respectively for the catalyst dosage optimization. Rate of reaction on colour removal and COD degradation were behaved in first order with kinetic rate constant was 0.004 . Performance of COD degradation was achieved better with catalyst $\mathrm{TiO}_{2}$.

Key Words: Wet air oxidation, Optimization, Black liquor.

\section{INTRODUCTION}

Several countries has been prompted by the potential hazards associated with industrial effluents and coupled to limit the indiscriminate discharge of untreated wastewaters ${ }^{1}$. The pulp and paper industry has been among the most significant of industrial polluters of the waterways, and therefore has been one of the industries of concern. The pulp and paper industry produces large quantities of brown/black effluent that primarily result from pulping, bleaching, and paper-making production stages. The dark color and toxicity of pulp-paper mill effluent comes primarily from lignin and its chlorinated derivatives (e.g., lignosulphonic acid, resins, phenols, and hydrocarbons) that are released during various processing steps of lignocellulosic materials. Various physico-chemical remediation treatments in the pulp-paper industry are now used, or have been suggested, but often are not implemented, because of the high cost involved. The conventional effluent treatment processes are not effective for their complete degradation. Hence, treatment with some advanced oxidation processes (AOP's) is needed ${ }^{2}$.

\section{EXPERIMENTAL}

Samples collected from various sources of streams were analyzed. The untreated black liquor effluent was found as alkaline $\mathrm{pH}$, high TSS, high TDS, high chloride, high COD, very high BOD, high sulphate, high AOX, high colour and traces of organic compounds.

Effluents from various streams of pulp and paper mill in Karur District were collected. Analysis of various parameters like core parameters, colour, AOX and organic pollutants were done. Core parameters were analyzed by the standard methods. Colour was analyzed by the spectrophotometer.

Advanced oxidation process was analyzed by coulometric titration method in ECS 1200 water module instrument. The sample was adsorbed on the activated charcoal in the preparatory phase. The charcoal bearing adsorbed analytical sample was slid in to the furnace on a boat and burnt in a flow of oxygen at $1200{ }^{\circ} \mathrm{C}$.

Organics and chloro-organics were analyzed in GC-MS (SHIMADZU QP 2010) with Purge and Trap. Software used was GC-MS solution version 2.53. The research was selected to treat the black liquor effluent by wet air oxidation method at higher temperature and pressure without catalyst, with catalyst copper sulphate and $\mathrm{TiO}_{2}$. The chemicals used for the analysis are catalysts $\left(\mathrm{TiO}_{2}\right)$ and copper sulphate.

Characterization of the black liquor: For this experimental study, the wastewater was collected from the pulp and paper mill which is located in Karur District, India. Samples were pre-analyzed for its characteristics parameters like colour, COD, BOD, AOX, chloroorganics, etc. by employing the 
methods detailed in the standard methods for the examination of water and wastewater ${ }^{3}$.

The effluent from the raw material preparation section was low in BOD and COD, but contains some amount of floating and readily settable solids such as dust, grit and sand. A digester house effluent was low in volume and dark brown in colour due to lignin. It has high BOD and COD. Pulp washing effluent was highly coloured and large in volume, but low in BOD and COD compared to bulk washing effluents. It was also brown in colour due to caustic extraction effluent. The $\mathrm{pH}$ value of the wastewater was slightly acidic ${ }^{4-7}$. The black liquor was the most polluting among the different streams. Black liquor, if not segregated, ends up in pulp washing wastewater. The pulp washing section contributes nearly 80-82\% of the total pollution load.

Experimental setup: The experimental setup of the WAO treatment process is shown in Fig. 1. The experiments was carried out in autoclave reactor, made up of stainless steel, the reactor was equipped with heating coil, temperature indicator, gas inlet, pressure gauge and safety head port on the top head. Effluent port was provided on the bottom of the reactor. Air was supplied to meet the oxygen for oxidation of the pollutants by using an air compressor.

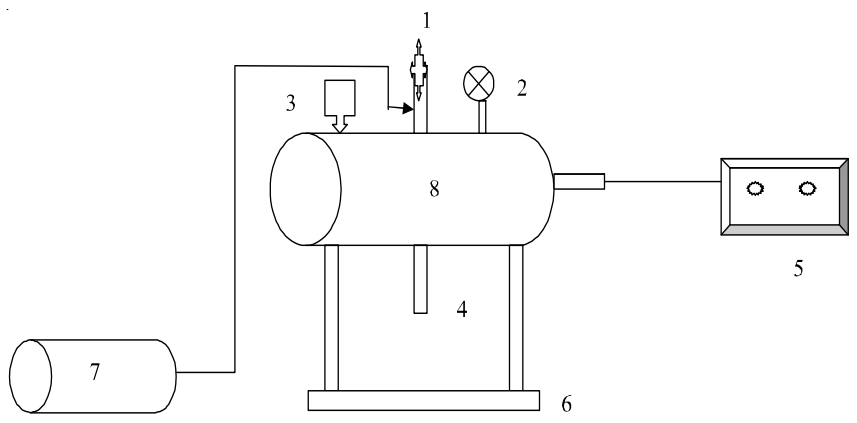

Fig. 1. Experiment setup of WAO. 1. Inlet valve, 2. Pressure gauge, 3. Pressure release valve, 4. Outlet valve, 5. Temperature indicator, 6. Standing rod, 7. Compressor air 8. 8. Wet air oxidation reactor

The design specifications of the reactor are given below: Capacity - 20 L, Material - Stainless steel, maximum temperature- $180{ }^{\circ} \mathrm{C}$, maximum pressure -8 bar.

Procedure: The method of WAO of industrial wastewater from pulp and paper was investigated in a reactor supported with catalysts.

The methodology consist of (a) Fabrication of reactor for WAO process. (b) Characterization of black liquor wastewater. (c) Conducting preliminary studies. (d) Conducting lab scale feasibility studies to study the effect of $\mathrm{pH}(8,9,10,11,12$ and 13), catalyst dosage $(1.0,2.0,3.0,4.0$ and $5.0 \mathrm{~g} / \mathrm{L})$, reactor temperature-( $\left.140-180^{\circ} \mathrm{C}\right)$, reactor pressure $(5.0-7.0 \mathrm{Kg} / \mathrm{sq} \mathrm{cm})$ and contact time (0-3 h). (e) Analysis of COD removal in wastewater sample. (f) Determination of kinetics of WAO process.

The experimental studies were performed to study the effect of $\mathrm{pH}$, catalyst dosage, temperature and contact time on WAO process for black liquor treatment. Initially, liquid solution was blended with catalyst, then added into the reactor and then tightly soaked. Compressed Air was then supplied into the reactor through the inlet for increasing pressure.

\section{RESULTS AND DISCUSSION}

\section{Effect of pH on COD removal}

Effect of $\mathbf{p H}$ on COD removal without catalyst: The $\mathrm{pH}$ for the raw pulp and paper black liquor sample was found as 12 on COD degradation. The COD for the raw pulp and paper black liquor sample was found as $1,14,000 \mathrm{mg} / \mathrm{L}$. The effect of $\mathrm{pH}$ on COD degradation was studied for the samples by varying $\mathrm{pH}$ at range of 8-13 keeping temperature at $160^{\circ} \mathrm{C}$, pressure at $6.5 \mathrm{Kg} / \mathrm{sq} \mathrm{cm}$ and contact time of $1 \mathrm{~h}$. Black liquor samples have been treated without catalyst, the COD in $\mathrm{mg} / \mathrm{L}$ observed were in the value of $84000,83200,74000,60000$,

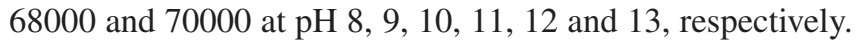
The percentage COD degradation efficiency was in the value of 27, 27, 35, 47, 40 and 38, respectively. The $\mathrm{pH}$ has been optimized at 11 as shown in the Fig. 2.
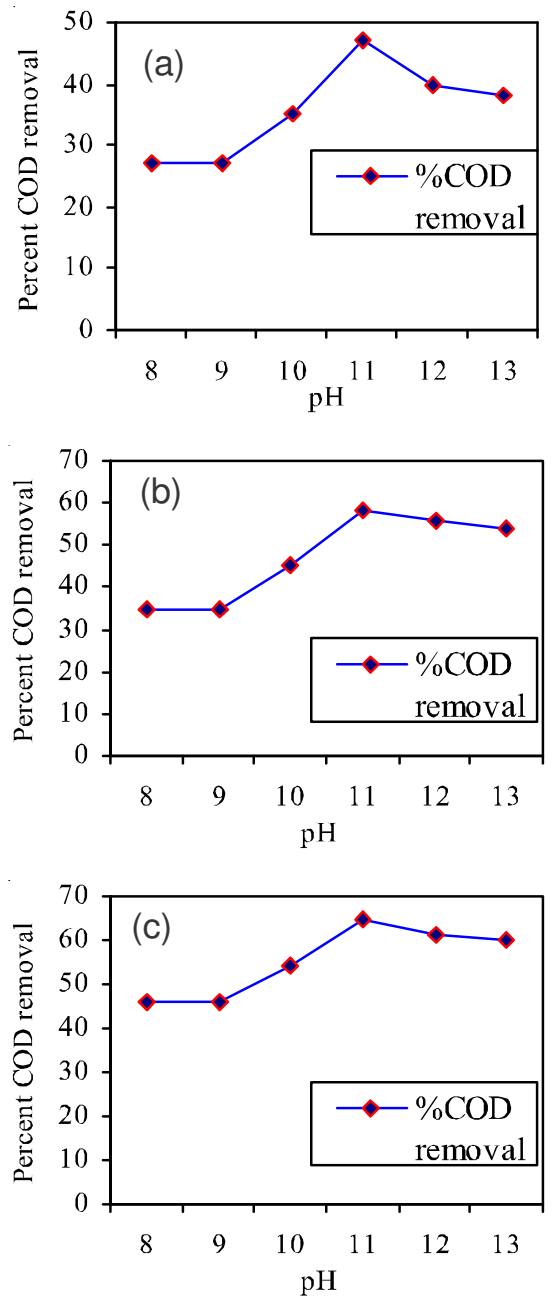

Fig. 2. (a-c) Effect of $\mathrm{pH}$ on COD degradation without catalyst, with copper sulphate and titanium dioxide

Effect of pH on COD removal with catalyst copper sulphate: Black liquor samples have been treated with $\mathrm{CuSO}_{4}$ keeping temperature as $160{ }^{\circ} \mathrm{C}$, Pressure as $6.5 \mathrm{Kg} / \mathrm{sq} \mathrm{cm}$, contact time of $1 \mathrm{~h}$ and dosage of $1.00 \mathrm{~g} / \mathrm{L}$, the COD in $\mathrm{mg} / \mathrm{L}$ observed were in the value of 73500, 74000, 62150, 48000,

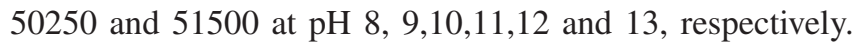
The percentage COD degradation efficiency was in the value 
of $35,35,45,58,56$ and 54 , respectively. The $\mathrm{pH}$ was optimized at 11 for the above samples as shown in Fig. 2 b.

Effect of pH on COD removal with catalyst titanium dioxide: Black liquor samples have been treated with $\mathrm{TiO}_{2}$ keeping temperature as $160{ }^{\circ} \mathrm{C}$, pressure as $6.5 \mathrm{~kg} / \mathrm{sq} \mathrm{cm}$, contact time of $1 \mathrm{~h}$ and dosage of $1.00 \mathrm{~g} / \mathrm{L}$, the COD in $\mathrm{mg} / \mathrm{L}$ observed were in the value of $61600,61800,52150,40080$,

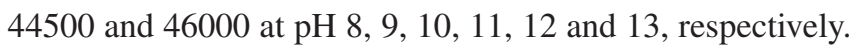
The percentage COD degradation efficiency was in the value of 46, 46, 54, 65, 61 and 60 , respectively. The $\mathrm{pH}$ was optimized at 11 for the above samples as shown in Fig. 2c.

TABLE-1

\begin{tabular}{ll}
\multicolumn{2}{c}{ TABOFILE OF A PAPER MILL INDUSTRY, KARUR } \\
\hline \multicolumn{1}{c}{ Parameters } & \multicolumn{1}{c}{ Description } \\
\hline Products manufactured & 400000 T/A \\
Effluent generation & 52500 KLD \\
Machineries used & $\begin{array}{l}\text { Wood cutting machine, digesters, } \\
\text { bleaching, soda recovery plant, paper } \\
\text { machines 3 numbers }\end{array}$ \\
Process method used & $\begin{array}{l}\text { Kraft paper } \\
\text { Treatment method followed }\end{array}$ \\
\hline
\end{tabular}

\section{Effect of contact time on COD removal}

Effect of contact time on COD degradation without catalyst: The effect of contact time on COD degradation was studied by varying time from 0 to $180 \mathrm{~min}$ at $15 \mathrm{~min}$ interval, at optimum $\mathrm{pH}$ of 11 keeping temperature at $160^{\circ} \mathrm{C}$, pressure at $6.5 \mathrm{Kg} / \mathrm{sq} \mathrm{cm}$. COD for the raw effluent was $1,12,000 \mathrm{mg} /$ L. Black liquor samples have been treated without catalyst, the COD in $\mathrm{mg} / \mathrm{L}$ observed were in the value of 92000,83000 , $78050,62000,60050,58650,57560,54750,52850,48650$, 46020 and 44000 at contact time of $15,30,45,60,75,90$, $105,120,135,150,165$ and 180, respectively. The percentage COD degradation efficiency was in the value of $18,26,30$, $45,46,48,49,51,53,56,59$ and 61 , respectively. The contact time has been optimized at $3 \mathrm{~h}$ as shown in the Fig. 3 .

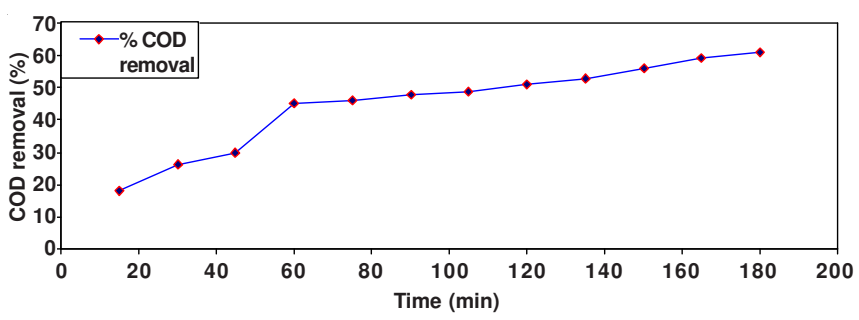

Fig. 3. Effect of contact time on COD degradation without catalyst

Effect of contact time on COD degradation with copper sulphate dosage: The effect of contact time on COD degradation was studied by varying time from 0 to $180 \mathrm{~min}$ at $15 \mathrm{~min}$ interval, at optimum $\mathrm{pH}$ of 11 keeping temperature at $160{ }^{\circ} \mathrm{C}$, pressure at $6.5 \mathrm{~kg} / \mathrm{sq} \mathrm{cm}$. COD for the raw effluent was 108000 $\mathrm{mg} / \mathrm{L}$. Black liquor samples have been treated with catalyst copper sulphate at $1.0 \mathrm{~g} / \mathrm{L}$ dosage, the COD in $\mathrm{mg} / \mathrm{L}$ observed were in the value of $86000,72000,62000,51000,48000$, $47000,46500,45900,43020,41000,38050$ and 37100 at contact time of $15,30,45,60,75,90,105,120,135,150,165$ and 180 , respectively. The percentage COD degradation efficiency was in the value of $20,33,43,53,56,56,57,58$,
$60,62,65$ and 66, respectively. The contact time has been optimized at $3 \mathrm{~h}$ as shown in the Fig. 4.

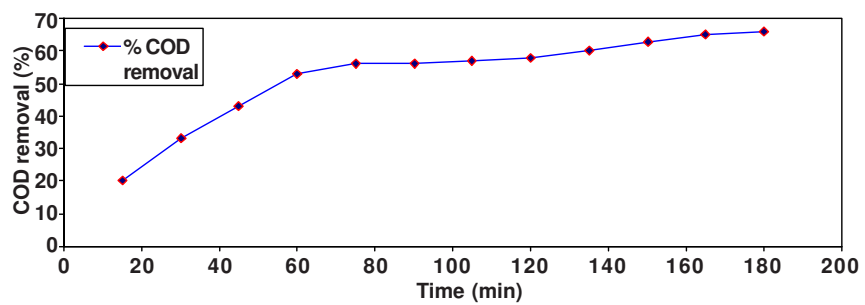

Fig. 4. Effect of contact time on COD degradation with copper suphate dosage

Effect of contact time on COD degradation with titanium dioxide dosage: The effect of contact time on COD degradation was studied by varying time from 0 to $180 \mathrm{~min}$ at 15 min interval, at optimum $\mathrm{pH}$ of 11 keeping temperature at $160{ }^{\circ} \mathrm{C}$, pressure at $6.5 \mathrm{Kg} / \mathrm{sq} \mathrm{cm}$. COD for the raw effluent was $106500 \mathrm{mg} / \mathrm{L}$. Black liquor samples have been treated with catalyst titanium dioxide at $1.0 \mathrm{~g} / \mathrm{L}$ dosage, the COD in $\mathrm{mg} / \mathrm{L}$ observed were in the value of $75000,65100,54000$, 44200, 44000, 43800, 42000, 40800, 38600, 36000, 33000, 31050 at contact time of $15,30,45,60,75,90,105,120,135$, 150,165 and $180 \mathrm{~min}$, respectively. The percentage COD degradation efficiency was in the value of $30,39,49,58,59,60,62$, 64, 66, 69 and 71, respectively. The contact time has been optimized at $3 \mathrm{~h}$ as shown in the Fig. 5.

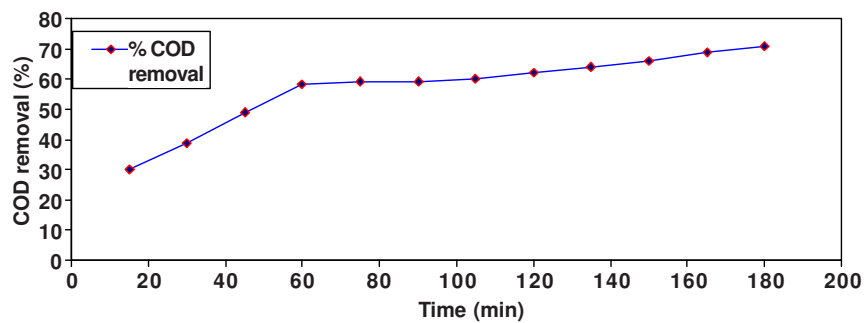

Fig. 5. Effect of contact time on COD degradation with titanium dioxide dosage

\section{Effect of catalyst dosage on COD removal}

Effect of catalyst dosage on COD degradation with catalyst copper sulphate: The effect of catalyst dosage on COD degradation was studied by varying copper sulphate dosage from $1.00-5.00 \mathrm{mg} / \mathrm{L}$ at $1.00 \mathrm{mg} / \mathrm{L}$ interval, at optimum $\mathrm{pH}$ of 11 and contact time of $3 \mathrm{~h}$ keeping temperature at $160{ }^{\circ} \mathrm{C}$, pressure at $6.5 \mathrm{~kg} / \mathrm{sq} \mathrm{cm}$. COD for the raw effluent was 114000 $\mathrm{mg} / \mathrm{L}$. The COD in $\mathrm{mg} / \mathrm{L}$ observed were in the value of 42000 , $39100,36000,35800$ and 34800 at catalyst dosage of 1.0, 2.0, 3.0, 4.0 and $5.0 \mathrm{~g} / \mathrm{L}$, respectively. The percentage COD degradation efficiency was in the value of 63, 66, 68, 69 and 69 , respectively. The catalyst dosage was optimized at $4.0 \mathrm{~g} / \mathrm{L}$ as shown in the Fig. 6.

Effect of catalyst dosage on COD degradation with titanium dioxide: The effect of catalyst dosage on COD degradation was studied by varying titanium dioxide dosage from $1.0-5.0 \mathrm{mg} / \mathrm{L}$ at $1.0 \mathrm{mg} / \mathrm{L}$ interval, at optimum $\mathrm{pH}$ of 11 and contact time of $3 \mathrm{~h}$ keeping temperature at $160^{\circ} \mathrm{C}$, pressure at $6.5 \mathrm{~kg} / \mathrm{sq} \mathrm{cm}$. COD for the raw effluent was $114000 \mathrm{mg} / \mathrm{L}$. The COD in $\mathrm{mg} / \mathrm{L}$ observed were in the value of 36000,34000 , 


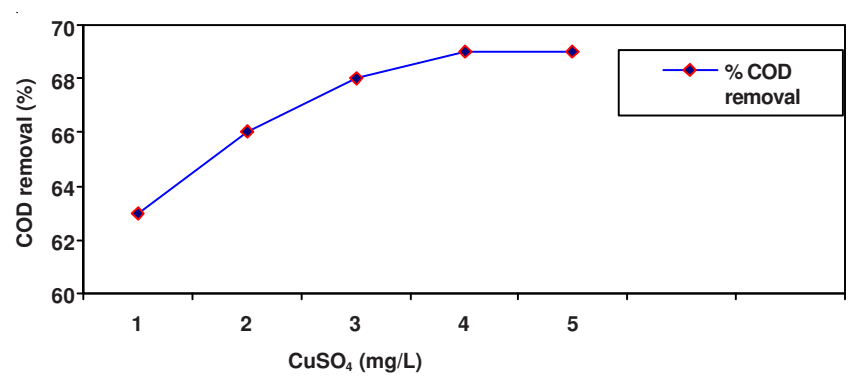

Fig. 6. Effect of copper sulphate dosage on COD removal

32000, 30000 and 29500 at catalyst dosage of 1.0, 2.0, 3.0, 4.0 and $5.0 \mathrm{~g} / \mathrm{L}$, respectively. The percentage COD degradation efficiency was in the value of $68,70,72,74$ and 74 , respectively. The catalyst dosage was optimized at $4.0 \mathrm{~g} / \mathrm{L}$ as shown in the Fig. 7.

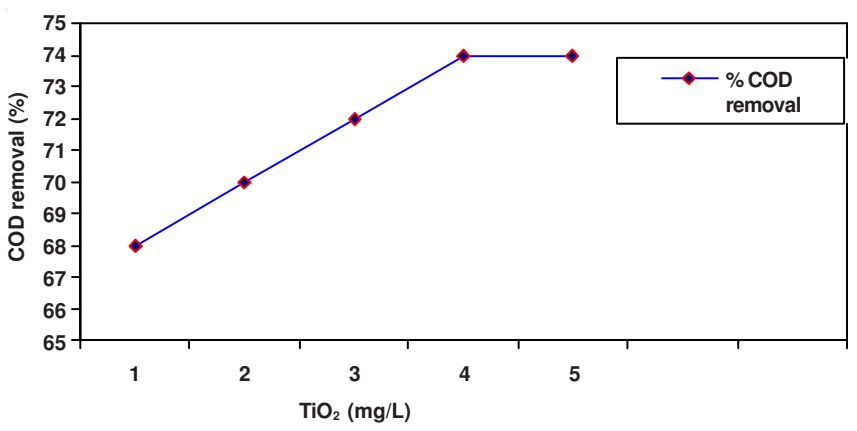

Fig. 7. Effect of titanium dioxide dosage on COD removal

Formation of AOX: In the wet air oxidation process, formation of AOX as chlorine was found less than $0.1 \mathrm{mg} / \mathrm{L}$ against the International Standard of $1 \mathrm{mg} / \mathrm{L}$. In the batch treatment of acetone, maximum AOX formation was observed with $10,000 \mathrm{mg} / \mathrm{L} \mathrm{Cl}$ at $\mathrm{pH} 10$ and for ABS $10,000 \mathrm{mg} / \mathrm{L} \mathrm{Cl}$ at $\mathrm{pH}$ 3 . The range of AOX concentration in the final effluent from the paper industries were 4.96-6.73 $\mathrm{mg} / \mathrm{L}$. In the bleaching and dyeing effluents AOX value was $0.4 \mathrm{mg} / \mathrm{L}$. In the bleaching effluents the AOX values were 13.05 and $13.34 \mathrm{mg} / \mathrm{L}$. AOX was noticed in the treated effluents as traces.

Kinetics of WAO: The generalized kinetic model is based on the assumption that some of the initial organic compounds present in the wastewater were directly oxidized to the end product $\left(\mathrm{CO}_{2}\right.$ and $\left.\mathrm{H}_{2} \mathrm{O}\right)$, in the WAO treatment process ${ }^{8-9}$. The first order kinetic model is given by equation.

$$
\ln \left(\frac{\mathrm{C}}{\mathrm{C}_{0}}\right)=-\mathrm{kt}
$$

where, $\mathrm{C}_{\mathrm{o}}$-initial $\mathrm{COD}, \mathrm{C}$ - final $\mathrm{COD}, \mathrm{t}=$ time and $\mathrm{k}=$ first order rate coefficient.

From the kinetic study conducted with optimized operating parameters and from the graph, the kinetic rate constant (k) was obtained. Graph was plotted taking the contact time on the $\mathrm{X}$-axis and \% COD removal values in the Y-axis. Data was fed in the zero, first and second order equations and graphs were plotted accordingly. It was inferred that the reactions takes place in the first order because the value of regression (0.868-0.932) was more linear (straight) than other two order of reactions. Kinetic rate constant was found as $0.004 \mathrm{~min}^{-1}$. Inactivation of indicator bacteria in wastewater by chlorine behaved in first order reaction with $\mathrm{k}$ value less than $1 \mathrm{~min}^{-1}$. A new method for calculation of the chlorine demand of natural and treated waters behaved in first order reaction with $\mathrm{k}$ value $3.68 \mathrm{~min}^{-1}$. The heterogeneous photocatalytic degradation of reactive dyes $\mathrm{B} 15, \mathrm{R} 239$ and $\mathrm{Y} 17$ by $\mathrm{TiO}_{2} / \mathrm{UV}$ behaved in first order reactions with $\mathrm{k}$ values are 2.6 and $0.011 \mathrm{~min}^{-1}$.

\section{Conclusion}

Experiment was conducted at $160{ }^{\circ} \mathrm{C}$ temperature and 6.5 $\mathrm{kg} / \mathrm{sq} \mathrm{m}$ pressure. The $\mathrm{pH}$, contact time and catalysts $\mathrm{TiO}_{2}$ and $\mathrm{CuSO}_{4}$ dosage were found optimized at $11,3 \mathrm{~h}$ and $4.0 \mathrm{mg} / \mathrm{L}$, respectively. The percentage of COD degradation was in the range of 27-47 without catalyst, 35-58 with catalyst $\mathrm{CuSO}_{4}$ and 46-65 with catalyst $\mathrm{TiO}_{2}$, respectively for the $\mathrm{pH}$ optimization, in the range of 18-61 without catalyst, 20-66 with catalyst $\mathrm{CuSO}_{4}$ and 30-71 with catalyst $\mathrm{TiO}_{2}$, respectively for the contact time optimization and in the range of 63-69 with catalyst $\mathrm{CuSO}_{4}$ and 68-74 with catalyst $\mathrm{TiO}_{2}$, respectively for the catalysts dosage optimization. Rate of reaction on COD degradation were behaved in first order with kinetic rate constant $0.004 \mathrm{~min}^{-1}$. Performance of COD degradation was achieved better with catalyst $\mathrm{TiO}_{2}$.

\section{REFERENCES}

1. S.K. Garg and M. Tripathi, Rev. Environ. Contam. Toxicol., 212, 113 (2011).

2. E.C. Catalkaya and F. Kargi, J. Environ. Manage., 87, 396 (2008).

3. R.A. Rahman, A.Y. Zahrim and A.A. Bakar, J. Appl. Sci., 7, 2160 (2007).

4. L.S. Clescerl, A.E. Greenberg and A.D. Eaton, Standard Methods for Examination of Water \& Wastewater, Washington, DC: American Public Health Association, edn 20, (1999); ISBN 0-87553-235-7.

5. K. Ranganathan, S. Jeyapaul and D.C. Sharma, Environ. Monit. Assess., 134, 363 (2007).

6. E. Oguza and B. Keskinler, J. Hazard. Mater., 151, 753 (2008).

7. M. Hashimoto, S. Taniguchi, R. Takanami, R.R. Giri and H. Ozaki, Water Sci. Technol., 62, 484 (2010).

8. J. Jin, M.G. El-Din and J.R. Bolton, Water Res., 45, 1890 (2011).

9. J.L. Acero, F.J. Benitez, F.J. Real and G. Roldan, Water Res., 44, 4158 (2010). 